斯樣な事實に鑒み，Hornavysky 氏の如きは，胃腸手術前に檢便を行つて，蟲卵(特に蜔蟲 卵)を检查し，若し卯を認めたならば，手術前に豫め蜔蟲驅除を行ふここを，獎勵しておる位で ある。

次に蜔蟲性腸閉塞 Askaris-Ileus こ云ふものは，腸管內多數蚼蟲の塊狀堆積によつて大なる 䞲狀の一塊を形成するここによつて，腸管を閉塞するのであつて，これは手術により又剖檢に より發見されておるものである，吾人も以前「イレウス」の手術に於て，小腸の蛔蟲集塊に因す る，閉塞性「イレウス」の1例に遭遇しておる。佔蜔蟲集塊に因る腸重積を報告せる人がある

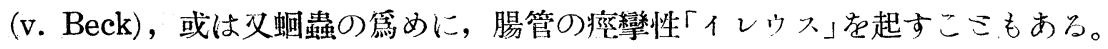
以上は蚼蟲の外科的疾患に關聯したる話を附記したる次第である。

\title{
「レントゲン画面撮影法の臨林的效用 (肺壞瘟手術の一例)
}

㮌天堂醫院レントゲン科醫學士 渡 邊 太 郎

「レントゲン」斷面撮影の裝置(「トモグラフ」或は「プラニグラフ」が令包賞院に設備された。 設備堂日から臨牀上に應用して大いにその效用を認めてるる次第であるが中にも肺壤监の 患者で手術の適否端にその方法を決定するに非常に役立つた例があるのでそれを立に報告す る。

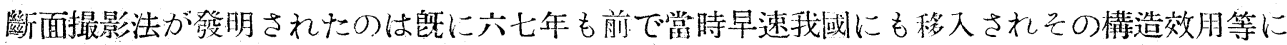
就ても屢了報告されてるるここであるから詳しい事を立站に絽り返す必要もあるまいが話の順序 こして簡單に說明すれば普通の「レントゲン」撮影は特殊の場合を除き常に人體の全層の像を撮 影し得るのみなるに反し斷面撮影法はその任意の層郎ち斷面の像のみを撮影する方法であつて その裝置は相對する「ンントゲン」管球こ「フィルム」こ苍 1 本の支柱で連絡し此の支柱の管球ミ 「フィルムミの中間の一點を軸こして之を一方から他方へ約 90 度振子の樣に移動せしめながら 撮影を行ふのである。然る時は運動の軸を含む水本面のみが常に焦點ミつフィルムさをつなぐ 線冈にあり從つて撮影中常に「レントゲン」線を受けてその像觉はつきり「フィルム」に印するこ こメなる。この軸炎上下に加減するここによつて任意の面を撮影するここが出來る。插圖（第 1 圖)によつて諒解されたい。

さて患者は 50 歲の男子で生來健康であつた。本年 2 月 28 日惡寒こ共に 39 度迄發熱した。 その後熱は弛張し左側胸部に疼痛があつて氣分が惡かつたのであるが 3 月 1 日から 3 日迄は强 いて起きて業務を執つた。3 日夕診察を受けて肺炎こ云はれた。その時熱は 38 度であつた。 


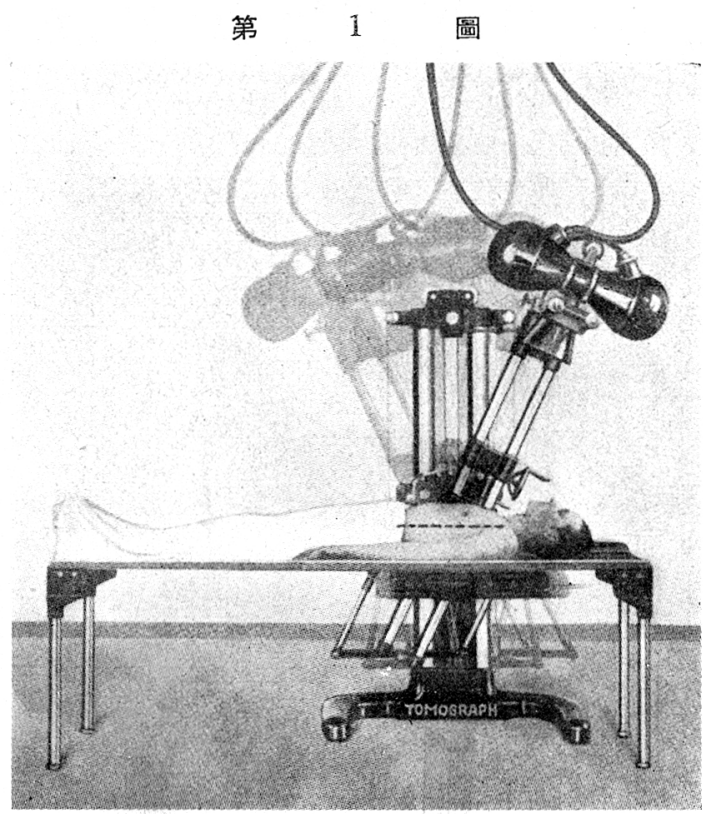

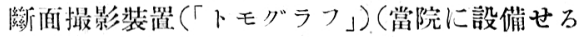
ものは本囯のものとは筫万)

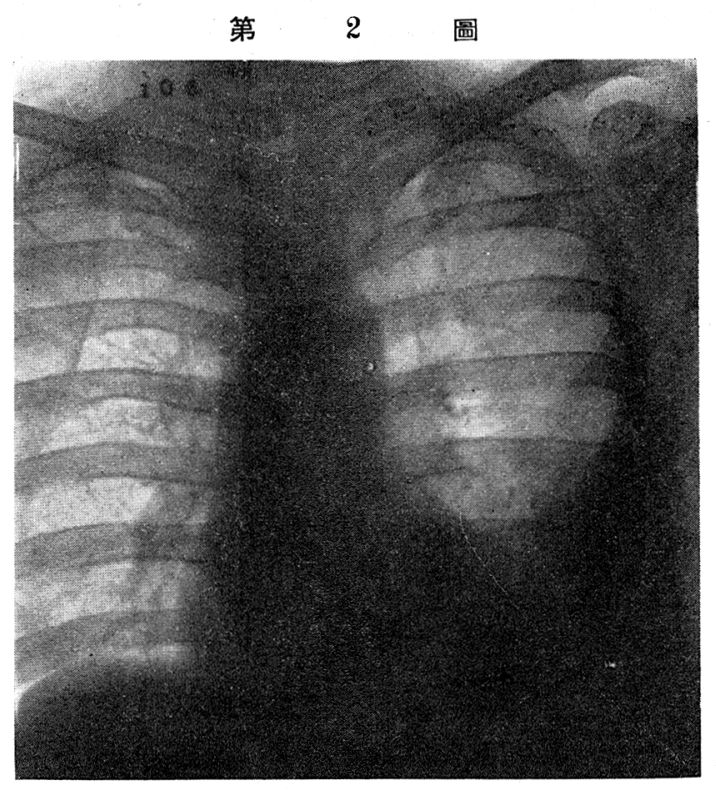

以來 37 度 5 分から 39 度の間学弛張し てるた，3月12日夜牛から急に咳嗽が 起つた。喀桨は多少あつたが多いこい ふ程ではなかつた。3月14日咳嗽に際 乙呼氣に息氣あるに氣付き喀痰量が多 くなつて某病院に入院したがその後も 喀痰量は多く息氣も低然こして去らな かつた。3 月下旬に至り息氣は幾分減 じ掞も少量ながら減じた。陔嗽は依に なるミやはり甚しかつた。4 月14日當 院に大院。當特右を下に乙て卧してる たが卧位により咳嗽には變りがないこ

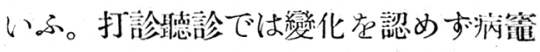
がごこにあるのか明かにし難かつた。 痰は膿樣で惡息があり 1 日 100-200

第 3 圖

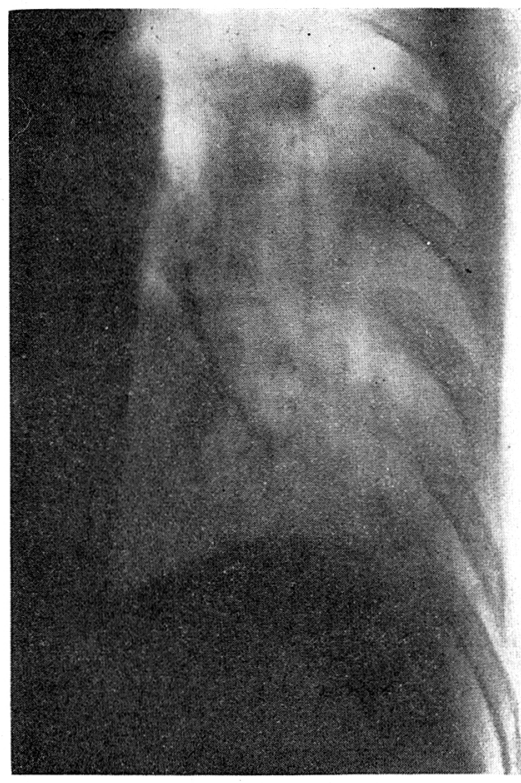

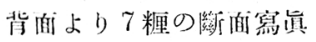

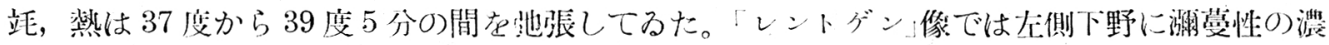

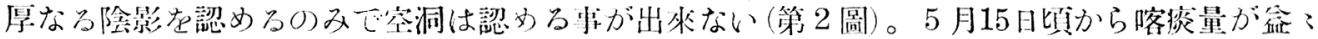

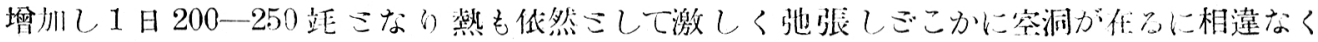




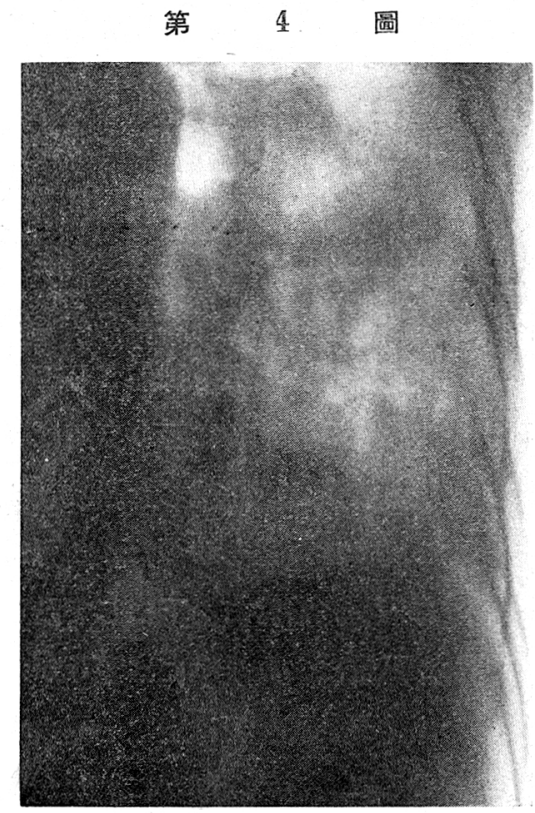

背面より 9 糎の炏䤄寫眞

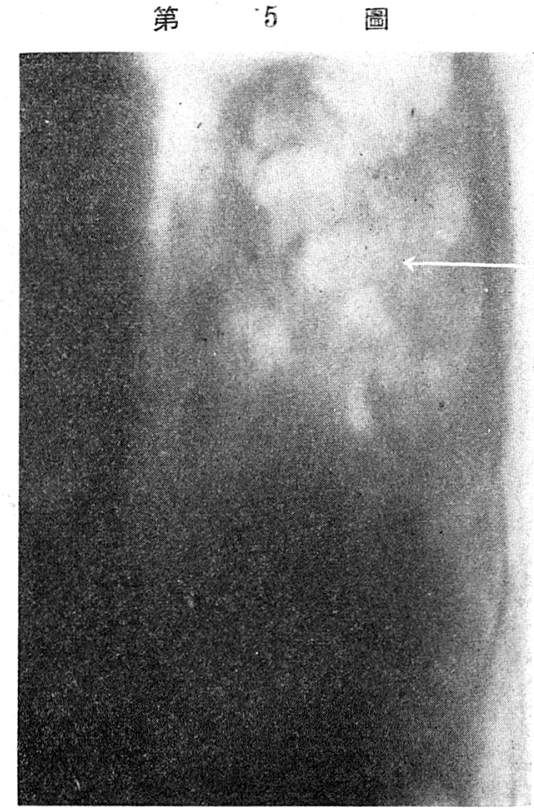

背面より 13 糎の嗞面寫真

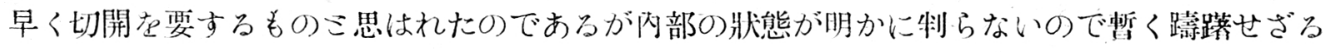

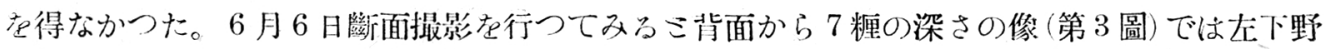

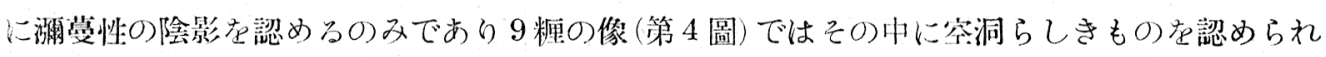
たのであるが 13 糎の像 (第5 5 圖)に至つて立派な空洞を數多認める事が出來た。背面から 13 糎 の梁さ郎ち胸面から約 5 糎の所であるから前胸壁から手迶を行つて豫期した場所で空洞に到達 し之症切開して多量の膿汒在排出した(佐藤博上手術)。切開後病狀は頓に好轉し常日から喀痰 量牥 1 日 20-30 站出出です熱は 37 度以下ミなつた。まここに憼くべき好成績であつた。

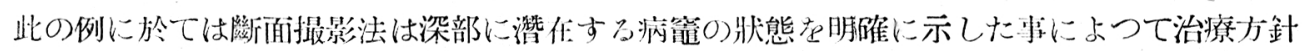
の確定及びその施行方法に就て賽に決定的の役制を演じたものこ云はねばならない。

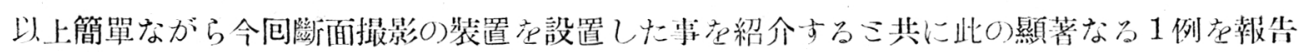
古当次第である。(15.6.15)

\section{肺畩㾞し胸腔内穿孔治驗の一例}

順天堂醫院外科小出敏治

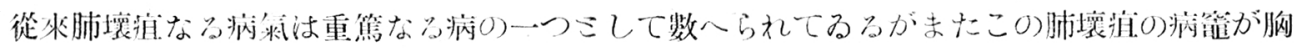

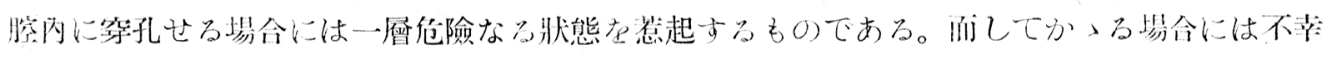
の轉蹛在取るこミも多く一般に死亡率の非常に高いものさされてるる。 